О.В. МАЛИШЕВСЬКИЙ

\title{
ПЕДАГОГІЧНІ УМОВИ ФОРМУВАННЯ ГОТОВНОСТІ ДО ПРОФЕСІЙНОЇ МОБІЛЬНОСТІ ІНЖЕНЕРІВ-ПЕДАГОГІВ КОМП'ЮТЕРНОГО ПРОФІЛЮ
}

\author{
() Малишевський О.В., 2019 \\ https://orcid.org/0000-0002-7653-7862 \\ http://doi.org/10.34142/2312-2471.2019.61.12
}

У статті обтрунтовано актуальність дослідження педагогічних умов формування готовності до професійної мобільності майбутніх інженерівпедагогів комп'ютерного профілю. Окреслено комплекс педагогічних умов досліджуваної якості. Перша умова - створення інформаиійного освітнього середовища, як педагогічної умови, щзо впливає на забезпечення єдиного інформаційного та професійного простору в професійній підготовці інженерів-викладачів у галузі комп'ютерних технологій. Друга умова інтеграція змістового, технологічного та методичного забезпечення інженерно-педагогічної підготовки. Акцентовано увагу на проектному значенні як умові розвитку творчого потенціалу майбутніх інженерів-викладачів. Визначено суть проектної діяльності. Це важливо для формування та розвитку комунікативного потенціілу майбутнього фахівия та адаптивних якостей співробітництва в колективі. Виділено етапи проектування та типи проектів, необхідних для розвитку професійної готовності до мобільності. Забезпечення моніторингу як умови розвитку досліджуваної якості є певним технологічним прочесом. Це передбачає прочедуру визначення компонентів готовності, їхніх критеріїв, показників, розробки та впровадження загальної моделі моніторингу. Визначено, щзо педагогічні умови формування готовності до професійної мобільності інженерів-педагогів комп'ютерного профілю передбачають сукупність педагогічних заходів $і$ суб' єкт-суб 'єктних стосунків. Вони допомагають підвищчтти ефективність професійної підготовки. Наголошено, щзо реалізація педагогічних умов сприяє изілісності системи формування готовності до професійної мобільності, забезпечує позитивну динаміку саморозвитку та самоудосконалення майбутніх інженерів-педагогів компютерного профілю. Перспективи подальиих розвідок з формування готовності до професійної мобільності майбутніх інженерів-педагогів комп'ютерного профілю пов'язані із дослідженням шляхів підвищення ефективності їх фахової підготовки засобами проєктної технології навчання.

Ключові слова: педагогічні умови, професійна мобільність, інженерипедагоги комп'ютерного профілю, проєктувальна діяльність, інформаційне освітнє середовище, інтеграція змісту фахової підготовки, моніторинг. 


\section{Malyshevskyi O. V. Pedagogical Conditions for Readiness Formation of} Professional Mobility for Engineers-Teachers in the Field of Computer technology

The article substantiates the study relevance of pedagogical conditions for readiness formation of professional mobility of future engineers-teachers in the field of computer technology and increase of their professional training effectiveness. The complex of pedagogical conditions of the studied quality has been outlined. Creating an information educational environment as a pedagogical condition affects the essence of a single information and professional space in vocational training engineers-teachers in the field of computer technology. The second condition is the content integration, technological and methodological support of engineering and pedagogical training. Emphasis has been placed on the design importance as the condition for the creative potential development of future engineers-teachers. The essence of the design activity has been determined. The design is important for the formation and development of future specialist's communicative potential and cooperation adaptive qualities in a team. The design stage and project types required for professional mobility readiness development have been highlighted. Ensuring monitoring as a condition for the studied quality development is a certain technological process. It provides a procedure for determining the readiness components, their criteria, indicators, development and implementation of a common monitoring model. It has been noted that the pedagogical conditions for readiness formation of professional mobility of future engineers-teachers in the field of computer technology provide a set of pedagogical activities and subject-subject relations. They help to increase professional training effectiveness. It has been also emphasized that the implementation of the above mentioned pedagogical conditions contributes to the integrity of the formation system of readiness for professional mobility, provides positive dynamics of self-development and self-improvement of future engineers-teachers in the field of computer technology. The prospects for further exploration of readiness formation of professional mobility of future engineers-teachers in the field of computer technology are associated with the study of ways to improve the effectiveness of their professional training by means of project-based learning technology.

Key words: pedagogical conditions, professional mobility, engineers-teachers in the field of computer technology, design activity, information educational environment, integration of professional training content, monitoring.

Постановка проблеми. Ринок праці у XXI столітті вимагає максимальної готовності випускників закладів професійної освіти до професійної мобільності. Водночас, недостатній рівень іiі сформованості у майбутніх інженерів-педагогів комп'ютерного профілю не узгоджується із потребами сучасного суспільства. Необхідною умовою для розв'язання цієї проблеми $є$ розробка нових підходів щодо фахової підготовки інженерів-педагогів, що забезпечуватиме формування у них високої самоактуалізації і самореалізації на ринку праці, тобто професійної мобільності. 
Педагогічна підтримка розвитку професійної мобільності інженерівпедагогів комп'ютерного профілю у вищій школі передбачає організацію певного виду педагогічної діяльності щодо забезпечення актуалізації можливостей освітнього процесу і стимулювання внутрішнього потенціалу здобувачів вищої освіти. Окреслена проблема визначає актуальність розробки педагогічних умов формування готовності до професійної мобільності майбутніх інженерів-педагогів комп'ютерного профілю.

Аналіз останніх досліджень i публікацій. Педагогічні умови формування професійної мобільності майбутніх фахівців у галузі професійної освіти обгрунтовано у роботах Л. Вороновської, О. Діденко, В. Дюніної, І. Герасимової, С. Капліної, А. Львова, О. Любимової, Л. Сушенцевої, І. Хом’юк та інших. Так, до педагогічних умов О. Діденко відносить розвиток навичок службового спілкування, формування умінь і прийомів самоосвітньої діяльності через залучення їх до різних видів самостійних і дослідницьких робіт, впровадження до освітнього процесу методів i прийомів, що забезпечують оволодіння сукупністю видів і способів професійної діяльності [1].

Л. Вороновська вважає, що успішне формування професійної мобільності майбутніх фахівців комунального господарства потребує реалізації таких педагогічних умов: «спрямованість змісту професійної підготовки на усвідомлення студентами динамічності вимог до фахівців комунального господарства, шляхів фахової самореалізації; залучення студентів до розмаїття форм комунікації у професійному просторі; забезпечення диверсифікації траєкторії професійної підготовки та фахової самореалізації студентів» [2, c. 115].

До педагогічних умов формування професійної мобільності майбутніх інженерів І. Хом'юк відносить: створення адекватного навчального середовища, створення позитивної мотиваційної настанови на професійну мобільність, використання засобів інтерактивного навчання як важливої складової адекватного освітнього середовища [3, с. 18].

Отже, у своїх дослідженнях науковці визначають педагогічні умови як багатоаспектний процес формування професійної мобільності майбутнього фахівця і пропонують різноманітні шляхи удосконалення досліджуваної якості у системі інженерно-педагогічної освіти.

Виділення невирішених раніше частин загальної проблеми. Однак проблеми формування готовності до професійної мобільності майбутніх інженерів-педагогів комп'ютерного профілю не знайшли належного відображення у публікаціях і вимагають додаткового вивчення.

Мета статті - дослідження педагогічних умов формування готовності до професійної мобільності майбутніх інженерів-педагогів комп'ютерного профілю.

Виклад основного матеріалу дослідження. У сучасній науковій літературі педагогічні умови визначають як: сукупність засобів, спрямованих на підвищення ефективності педагогічної діяльності [4]; ключовий фактор педагогічно комфортного середовища [5]; сукупність взаємозалежних і 
взаємообумовлених заходів педагогічного процесу, які забезпечують досягнення конкретної мети [6, с. 79]; обставини, від яких залежить та відбувається цілісний продуктивний педагогічний процес професійної підготовки фахівців, що опосередковується активністю особистості [7, с. 143].

Також це цілеспрямоване педагогічне спілкування; креативностимулююча діяльність (створення ситуації успіху); науково-методичне забезпечення педагогічного процесу формування духовних цінностей $[8$, с. 103]; система, складовими якої є певні норми, методи, умови, ситуації, що об'єктивно склалися та є необхідними для досягнення певної педагогічної мети [9, с. 183]. Однак, у зв'язку із багатоаспектністю досліджуваного феномена неможливо передбачити усі педагогічні умови, що впливають на процес формування готовності до професійної мобільності. Отже, зупинимося тільки на тих, які найбільш суттєво впливають на ефективність формування готовності до професійної мобільності майбутніх інженерів-педагогів комп'ютерного профілю.

У контексті вищезазначеного окреслимо комплекс педагогічних умов. Перша умова - це забезпечення єдиного інформаційно-професійного поля фахової підготовки інженерів-педагогів комп'ютерного профілю шляхом створення інформаційного освітнього середовища. Дотримання цієї педагогічної умови забезпечуватиме: гнучкість і комфортність освітнього процесу, що дозволить здобувачеві вищої освіти обрати оптимальний для себе маршрут опанування майбутньою професією; орієнтацію навчання на основні види майбутньої професійної діяльності; відкритість освітнього процесу забезпечення швидкого доступу до навчальної інформації у достатньому обсязі з різних місць, у різний час, різними технічними засобами.

Отже, практична реалізація інформаційного освітнього середовища для формування готовності до професійної мобільності сприяє позитивній мотивації до освітньої, наукової, професійно зорієнтованої діяльності; активному впровадженню інформаційно-комунікаційних технологій фахової підготовки, підвищенню іï ефективності та якості.

Друга умова - інтеграція змісту, технологічного i методичного забезпечення інженерної та педагогічної підготовки майбутніх фахівців комп'ютерного профілю, спрямованість іiі на формування готовності до професійної мобільності. При навчанні в інформаційному освітньому середовищі головною цінністю $є$ інформація, знання, необхідні для опанування професією. У контексті синергетичних концептів нашого дослідження та особливостей підготовки інженерів-педагогів комп'ютерного профілю інформація, що надходить до суб'єкта освітньої діяльності, має відповідати сучасному рівневі міжпредметних знань, тобто бути інтегративною. Інтегративний характер підготовки дозволяє зробити освітній процес більш цілеспрямованим.

Розглядаючи ефективність 3 позицій інтеграції, вважаємо, що професійно зорієнтований інформаційний супровід усіх видів освітньої діяльності сприятиме оптимальному досягненню цілей системи підготовки майбутніх фахівців. Крім того, зміст професійної підготовки інженерів-педагогів має 
орієнтуватися на теоретичні та інструментальні основи професійної мобільності, розвиток професійних та особистісних якостей професійно мобільного фахівця.

Технологічний супровід фахової підготовки реалізується впровадженням інноваційних, інформаційних, виробничих, психолого-педагогічних технологій, а методичний супровід - розробкою і впровадженням комплексу професійно зорієнтованого навчально-методичного забезпечення.

Сутність досліджуваної педагогічної умови полягає у тому, що вона не тільки забезпечує розширення інженерно-педагогічного інформаційного поля, а й мобілізує потребу у самонавчанні, саморозвиткові, спонукає до прояву вертикальної і горизонтальної мобільності. Отже, спрямований на досягнення спільної мети інтегративний зміст підготовки у поєднанні 3 технологічним i методичним супроводом доповнює спеціальне інформаційне освітнє середовище i сприяє розвиткові готовності до професійної мобільності у кожного суб'єкта освітньої діяльності.

Третя умова - розвиток творчого потенціалу майбутніх інженерівпедагогів комп'ютерного профілю засобами проєктування - забезпечує активізацію проектної діяльності учасників освітнього процесу, визначення способів творчої діяльності, цілеспрямоване створення проблемних ситуацій $\mathrm{i}$ застосування необхідних методів розв'язування їх, своєчасне коригування освітньої діяльності. У межах нашого дослідження важливим $є$ формування у студентів готовності до творчої, інноваційної діяльності, під якою ми розуміємо освоєння новітніх освітніх та професійно зорієнтованих інформаційних i комунікаційних технологій. Такі технології дозволяють реалізувати різноманітні проєкти. Для формування готовності до професійної мобільності важливо озброїти студента вміннями не лише швидко адаптуватися до нових умов, а й передбачати нові тенденції розвитку інформаційного суспільства.

Розвиток творчого потенціалу майбутніх фахівців $є$ важливою умовою розкриття внутрішніх резервів кожного студента, що сприяє підвищенню якості їх освіти у цілому. Для цього необхідним є залучення до планомірної творчої діяльності, яку ми визначаємо через систему ознак, зокрема: якщо діяльність спрямована на розв'язання проблемних завдань; якщо діяльність пов'язана 3 усвідомленням суб'єктом нових для нього знань, як орієнтирів, основи для подальшої розробки алгоритму розв’язання задач; якщо діяльність відкриває для суб'єкта нові можливості опанування знань і на їхній основі забезпечує розв'язання різноманітних інженерно-педагогічних завдань. Акцентуємо, що творчий потенціал найбільш ефективно формується у проєктній діяльності.

Проєктувальна діяльність для сучасного інженера-педагога, будучи стрижневою в структурі його професійних обов’язків, вимагає формування ще у процесі підготовки майбутніх фахівців. Тому рівень готовності до професійної мобільності майбутнього інженера-педагога комп'ютерного профілю безпосередньо залежить від того, наскільки вільно він може здійснювати проєктувальну діяльність, тобто: формулювати завдання, знаходити спосіб вирішення, матеріалізувати його в інформаційному об'єкті, 
здійснювати перевірку ефективності його функціонування у реальних умовах, оформляти документацію до проєкту.

Під проєктувальною діяльністю розуміють діяльність студентів, спрямовану на засвоєння програмного матеріалу, яка здійснюється через створення освітнього проєкту, його оформлення i публічний захист. Досліджуючи особливості проєктувальної діяльності в освітньому процесі, вчені $[10 ; 11]$ дійшли таких узагальнень: 1) проєктувальна діяльність спрямована на розв'язання дидактичних завдань; 2) їі здійснення орієнтоване на самостійність здобувачів вищої освіти; 3) ключова проблема освітнього проєкту має бути особистісно значущою для майбутнього фахівця; 4) результат проєктувальної діяльності завжди має матеріальний носій. Такий вид діяльності реалізується переважно у межах методу проєктів.

Ми розглядаємо проєктування як один із напрямів діяльності в освітньому процесі, що забезпечує вирішення конкретних педагогічних завдань. Для вирішення завдань майбутнім фахівцям необхідно досліджувати ті теорії, які відображають закономірності розвитку об'єкта проєктування, 3'ясувати суперечності у його розвитку і функціонуванні у конкретних умовах, сформулювати власні ідеї, що дозволяють більш ефективно використовувати отримані дані.

У цьому контексті акцентуємо на значенні для формування готовності до професійної мобільності колективних, групових, парних проєктів, які розкривають комунікативний потенціал майбутніх інженерів-педагогів комп'ютерного профілю і розвивають адаптивні якості співпраці у колективі. У такому випадку проєктна діяльність передбачає певний рівень комунікації між учасниками проєкту, тобто професійну співпрацю.

Під професійною співпрацею розуміємо, у першу чергу, систему суб'єктсуб'єктних стосунків, до якої залучені усі учасники освітньої діяльності здобувачі вищої освіти, викладачі, представники баз практик. У контексті нашого дослідження професійну співпрацю розглядаємо як механізм узгодженості інтересів основних суб'єктів освітньої діяльності, що існує на засадах толерантності, взаєморозуміння, взаємоповаги, взаємодопомоги. На наше переконання, умова забезпечення професійної співпраці $\epsilon$ однією 3 найскладніших у реалізації за рахунок розмаїтості характерів суб'єктів освітньої діяльності, особистісних стосунків та їх цілей, а також рівня компетентності викладачів.

Залежно від характеру об'єкта проєктування, рівня поставлених завдань добирається такий комплекс теоретичних знань про об'єкт, який дозволить визначити його системні закономірності розвитку, внутрішні взаємозв'язки. Крім того, розробка освітніх проєктів спирається на особистий досвід студента.

Отже, при організації проєктної діяльності необхідно враховувати такі підходи до проєктування: змістовно-предметний, спрямований на засвоєння методології проєктування, пошук і розробку способів вирішення професійних проблем, і особистісний, метою якого $є$ реалізація задумів, мотивів, розвитку досвіду діяльності, педагогічних умінь, реалізації потреби у творчості, надання можливості вибору і проєктування власної діяльності тощо. 
Розглядаючи проєктування як цілеспрямовану діяльність 3 розв'язання певної задачі шляхом багатократного моделювання i прийняття рішень, акцентуємо на трьох основних етапах проєктування:

- винахідництво - діяльність майбутнього інженера-педагога 3 усвідомлення певної проблеми i пошуку способу іiі розв'язання (пошук i вивчення інформації з тематики проєкту, 3 використанням різних джерел інформації, як традиційних, так і сучасних); узагальнення отриманої інформації; вибір способу і методів виконання проєкту, що $є$ базою для наступного етапу проєктування;

- моделювання - оформлення виділених знань у вигляді таблиць, схем, графів, графіків, формул тощо для чіткого і наочного уявлення структури знань 3 дисциплін, міжгалузевих і міжпредметних зв'язків між ними, для чого створюється модель-конспект, описуються методи розв'язання, обираються педагогічні, програмні і технічні засоби, розробляється план реалізації проєкту;

- конструювання - впровадження проєкту, відповідно до складеного плану, оформлення результатів проєкту, підготовка презентації його захисту.

Для формування готовності до професійної мобільності можуть бути використані освітні проєкти різних типів: 1) дослідницький, спрямований на постановку i розв'язання професійно зорієнтованої проблеми (діяльність орієнтована на пошук нового способу розв'язання проблеми); 2) інформаційний - систематизована добірка інформації 3 певної проблеми (діяльність спрямована на підбір матеріалів, їх опрацювання, узагальнення i подання у вигляді статті, есе, методичної розробки тощо); 3) прикладний розкриває технологію вирішення конкретної проблеми або алгоритму діяльності, опис методу, системи рекомендації тощо (діяльність спрямована на побудову інформаційної моделі задачі, визначення міжпредметних зв'язків).

Отже, активна проєктувальна діяльність інженерів-педагогів комп'ютерного профілю в освітньому процесі забезпечує їх особистісний розвиток, надає освітньому процесу професійної спрямованості, допомагає встановити зв'язок теорії з практикою майбутньої професійної діяльності. Крім того, досліджувана умова створює благодатний грунт для розвитку творчого потенціалу здобувачів вищої освіти.

Четверта умова - забезпечення моніторингу формування готовності до професійної мобільності - передбачає своєчасне отримання інформації про готовність і здатність педагогічного колективу брати участь у процесі цілеспрямованого формування готовності до професійної мобільності інженерів-педагогів комп'ютерного профілю. Технологічний процес моніторингу містить послідовні процедури, що відповідають етапам формування досліджуваної якості: первинний (визначення компонентів готовності до професійної мобільності, їх показників, розробка методик і діагностик збору i опрацювання даних, визначення початкового рівня сформованості досліджуваної якості); поточний (розробка загальної моделі спостереження за процесом формування готовності до професійної мобільності упродовж освітнього процесу); заключний (проведення діагностування по завершенню навчання). 
Цінність умови постійного моніторингу полягає у тому, що вона створює передумови для проведення експериментально-дослідної роботи 3 метою визначення рівнів сформованості у майбутніх фахівців професійної освіти комп'ютерного профілю на різних етапах педагогічного експерименту, забезпечує експериментальну діяльність відповідним інструментарієм проведення діагностування і аналітичного опрацювання отриманих емпіричних даних та їх інтерпретацію.

Висновки. Підсумовуючи проведений вище аналіз, під педагогічними умовами розуміємо сукупність педагогічних заходів і суб'єкт-суб'єктних стосунків, що зумовлюють підвищення ефективності фахової підготовки інженерів-педагогів комп'ютерного профілю, формування позитивної мотивації, розвиток особистісних і професійних якостей, творчого потенціалу майбутніх фахівців, задоволення їхніх освітніх потреб, сприяють формуванню у них готовності до професійної мобільності. Педагогічні умови забезпечують цілісність і замкненість системи формування готовності до професійної мобільності.

Перспективи подальших розвідок 3 формування готовності до професійної мобільності майбутніх інженерів-педагогів комп'ютерного профілю пов'язані із дослідженням шляхів підвищення ефективності їх фахової підготовки засобами проєктної технології навчання.

\section{Jimepamypa}

1. Діденко О, Совва С. Обгрунтування педагогічних умов формування міжнародної правової культури майбутніх офіцерів-прикордонників. Вісник Національної академії Державної прикордонної служби Украӥни. Серія: Педагогіка. 2016. Вип. 4. URL : http://nbuv.gov.ua/UJRN/Vnadped_2016_4_8.

2. Вороновська Л. П. Формування професійної мобільності майбутніх фахівців комунального господарства : дис. ... канд. пед. наук: 13.00.04. Харків, 2016. $267 \mathrm{c}$.

3. Хом'юк I. В. Система формування професійної мобільності майбутніх інженерів машинобудівної галузі : автореф. дис. ... докт. пед. наук: 13.00.04. Київ, 2012. 37 с.

4. Посталюк Н. Ю. Творческий стиль деятельности: педагогический аспект. Казань: Издательство Казанского университета, 1989. 207 с.

5. Истомина С. М. Педагогическая импровизация как условие включения детей 6-7 лет в процесс музыкального творчества : автореф. дисс. ... канд. пед. наук: 13.00.07. Екатеринбург, 2005. 22 с.

6. Дубич К. В. Особистісно орієнтоване виховання студентів в умовах соціокультурного середовища вищого навчального закладу : дис. ... канд. пед. наук: 13.00.07. Рівне, 2007. 267 с.

7. Гончаренко С. У. [та ін.]. Професійна освіта: словник : навч. посібник / за ред. Н. Г. Ничкало. Київ: Вища школа, 2000. 380 с.

8. Алєксєєнко Т. Ф., Басюк Т. П., Бех І. Д. [та ін.]. Енциклопедія для фахівців соціальної сфери / за заг. ред. І. Д. Звєрєвої. Київ; Сімферополь: Універсум, 2012. 535 с. 
9. Пєхота О. М., Будак В. Д., Старєва А. М. [та ін.]. Підготовка майбутнього вчителя до впровадження педагогічних технологій/ за ред. І. А. Зязюна, О. М. Пехоти. Київ: Видавництво А.С.К., 2003. 240 с.

10. Морзе Н. В. Методика навчання інформатики : навч. посіб.: у 3 ч. / за ред. М. І. Жалдака. Київ: Навчальна книга, 2004. Ч. ІІ. : Методика навчання інформаційних технологій. $287 \mathrm{c}$.

11. Хилл П. Наука и искусство проектирования: методы проектирования, научное обоснование решений. Москва: Мир, 1973. 263 с.

\section{Referenses}

1. Didenko, O, Sovva, S. (2016). Obgruntuvannia pedahohichnykh umov formuvannia mizhnarodnoi pravovoi kultury maibutnikh ofitseriv-prykordonnykiv. Visnyk Natsionalnoi akademii Derzhavnoi prykordonnoi sluzhby Ukrainy. (Pedahohika), issue 4. URL : http://nbuv.gov.ua/UJRN/Vnadped_2016_4_8 (in Ukrainian).

2. Voronovska, L. P. (2016). Formuvannia profesiinoi mobilnosti maibutnikh fakhivtsiv komunalnoho hospodarstva. Candidate's thesis. Kharkiv (in Ukrainian).

3. Khomiuk, I. V. (2012). Systema formuvannia profesiinoi mobilnosti maibutnikh inzheneriv mashynobudivnoi haluzi. Extended abstract of doctor's thesis. Kyiv (in Ukrainian).

4. Postalyuk, N. Yu. (1989). Tvorcheskii stil deyatelnosti: pedagogicheskii aspekt. Kazan: Izdatelstvo Kazanskogo universiteta (in Russian).

5. Istomina, S. M. (2005). Pedagogicheskaya improvizatsiya kak uslovie vklyucheniya detei 6-7 let v protsess muzykalnogo tvorchestva. Extended abstract of candidate's thesis. Ekaterinburg (in Russian).

6. Dubych, K. V. (2007). Osobystisno oriientovane vykhovannia studentiv v umovakh sotsiokulturnoho seredovyshcha vyshchoho navchalnoho zakladu. Candidate's thesis. Rivne (in Ukrainian).

7. Honcharenko, S. U. [et al.]. (2000). Profesiina osvita: slovnyk. N. H. Nychkalo (Ed.). Kyiv: Vyshcha shkola (in Ukrainian).

8. Alieksieienko, T. F., Basiuk, T. P., Bekh, I. D. [et al.]. (2012). Entsyklopediia dlia fakhivtsiv sotsialnoi sfery. I. D. Zvierieva (Ed.). Kyiv; Simferopol: Universum (in Ukrainian).

9. Piekhota, O. M., Budak, V. D., Starieva, A. M. [et al.]. (2003). Pidhotovka maibutnoho vchytelia do vprovadzhennia pedahohichnykh tekhnolohii. I. A. Ziaziun, O. M. Piekhota (Eds.). Kyiv: Vydavnytstvo A.S.K. (in Ukrainian).

10. Morze, N. V. (2004). Metodyka navchannia informatyky. (Vols. 1-3); Vol. 2: Metodyka navchannia informatsiinykh tekhnolohii. M. I. Zhaldak (Ed.). Kyiv: Navchalna knyha (in Ukrainian).

11. Khill, P. (1973). Nauka i iskusstvo proektirovaniya: metody proektirovaniya, nauchnoe obosnovanie reshenii. Moskva: Mir (in Russian). 